\title{
FOLKLORE STUDIES AND ETHNOLOGY IN SLOVENIA I
}

\section{Mare Kõiva \& Andres Kuperjanov}

\begin{abstract}
The article introduces the projects, researchers and institutions of the Slovenian Academy of Sciences and Arts (SASA), focusing on folklore studies and ethnology. In the first part we will give an overview of research topics and publications of the Institute of Migration of the SASA and the folklore anthologies and publications of the Institute of Ethnology. We will take a closer look at the recent publications and projects of the renowned folklore theoretician Marija Stanonik (including her collection of regional lore, biblical motifs in folk songs, the lore of Slovenian soldiers in the German army, theoretical approaches).
\end{abstract}

Keywords: ethnology, folklore studies, folklore publications, migration, Slovenia.

During our two-week visit to the Institute of Ethnology of the Slovenian Academy of Sciences and Arts we witnessed a vigorous academic life in Ljubljana. In addition to daily work in the archives and the library of the academy, we visited several institutions involved in studying the same subjects, and established contacts with guests of the academy from Germany, Serbia, Australia, and Croatia. We attended interesting lectures and visited a display of Slovenian earliest manuscripts, experiencing warm collegial welcome everywhere we went.

The Slovenian Academy of Sciences and its institutions are located in the central city of Ljubljana as a cluster surrounding a sunny square. A bookstore selling the publications of the Academy's several institutions presents a wide range of original studies, series and translations, indicating a vivid academic life. Next to publications on specific areas of study, various interdisciplinary series and publications, as well as the whole paraphernalia of the Academy of Sciences, also the architecture and interiors of the buildings are attractively designed. Using smart interior design solutions, the extremely high and large space of several research institutions has been divided into private offices, laboratories and library facilities in bright colour schemes. 
The Slovenian Academy of Sciences and Arts (SASA) is the oldest research centre in Slovenia, which grew out of the $16^{\text {th }}$ century Jesuit schools specialising in theology and philosophy and the Academia Operosorum, established in 1693 in Ljubljana. The academy has presently 74 full members, 19 associated members and 84 correspondent members from foreign research centres who participate in the total of six sections. The academic sphere surrounding the Novi trg Square lies adjacent to a monumental library building and the university building.

With a slight sting we have to admit that Slovenia's huge leap in information technology and broadband solutions described in the Estonian press was all true. Computers are state of the art and powerful, with proper software and large monitors. Local bookstores offer similar facilities and surprised us with a wide range of scientific literature. Numerous publications are issued in the field of the humanities and social sciences in Slovenian language, and the selection of foreign literature is also wide.

We took particular interest in the Institute of Emigration with its research programs. Its research team of nine members is oriented to interdisciplinarity. Some projects are carried out in cooperation with other academic institutions in Slovenia, such as e.g. the umbrella topic Perception of Slovenian Integration Policy, as well as with Scandinavian and Central European countries. The research topics of the centre cover a wide range of issues, including $19^{\text {th }}-20^{\text {th }}$ century migration, issues on preserving culture and identity among the Slovenian diaspora, demographic tendencies in former Yugoslavia and Slovenia. Among the themes the most conspicuous ones are perhaps the activities of Slovenian missionaries in Africa and Southwest Asia, late migration between former republics of Yugoslavia, and also studies on the diaspora literature. As expected, the topics also include the integration of people who have returned to Slovenia and related problems. One of the major research projects has resulted in the registering of emigrant archives and museum pieces in France, Luxemburg, Sweden, Czech Republic and Croatia. The institute publishes a newsletter in English, which provides an overview of news, recent publications, conferences, and a journal Dve Domovini. razprave o izseljenstvu: Two Homelands. Migration Studies, which recent issues have been primarily in English. The 
articles in the Slovenian language are summarised in foreign languages. The institute also compiles a series of monographs entitled Migracije.

The population of Slovenians exceeds that of Estonians by a million, which is why our language, identity and cultural attitudes are similar, especially due to the analogous cultural patterns in the last few centuries. Slovenia has been under Austrian cultural influence, followed by a socialist Yugoslavian period. Our belonging to the (Balto-) German culture area and former membership in the Soviet Union for a number of years has resulted in similarities in culture and general attitudes. Both Es-

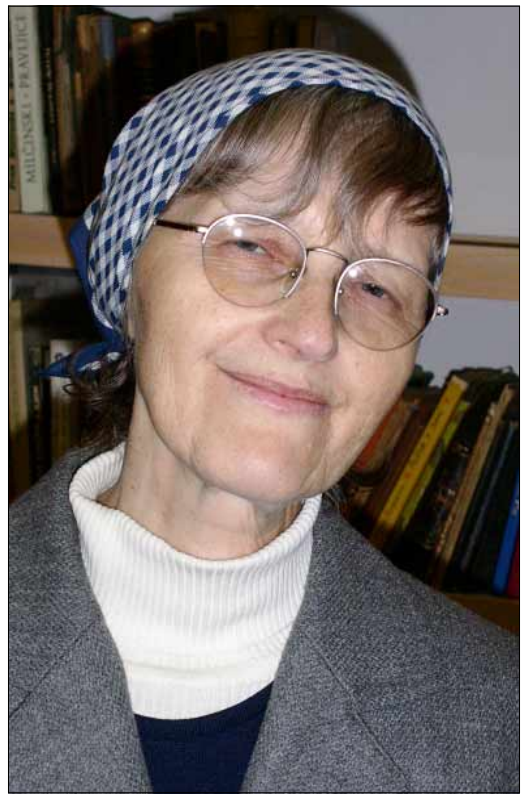

Photo 1. Marija Stanonik. Photo by Andres Kuperjanov, 2004. tonia and Slovenia have entered the second post-socialist decade. There are differences, of course, in landscape, village architecture, folk art, economic area, and, perhaps most conspicuously socialism, and the membership in the Non-Aligned Nations' Movement has enabled Slovenians more freedom of travel, wider range or research topics and scientific contacts. Similarities in the folklore of these two cultures, however, are astonishing.

Both folklorists and ethnologists work side by side in the Institute of Ethnology of the SASA. The number of scholars who study exclusively folkloric texts is currently smaller than the number of those who study regional identity, food tradition, rituals, or recent phenomena in the society.

One of the best known folklore theoreticians is Marija Stanonnik, whose articles in the past years have discussed, among other topics the different forms of folklore studies in Slovenia. She is theoretician by education and interests, has authored more than ten books, 
and is dedicated to studying the material that she herself regards as peripheral from the mainstream scholarly research - for example, examining the social activities and local history and oral history of her home village, which, besides other things, has given rise to a complex approach to the subject. Her major work, collecting folklore mostly by the means of a network of local teachers and school children, has resulted in an elaborately systematised manuscript archives, and a unique series of 28 beautifully designed hardcover volumes, conforming to academic requirements, and compiled by local authors under the supervision of the main editor Marija Stanonnik. The volumes include prefaces from linguists and ethnographers. Collected texts are published in dialectal varieties with retained phonetic idiosyncrasies. For the purposes of better understanding, the series includes a glossary and registers, attractive maps providing a schematic overview of the area and its location in Slovenia.

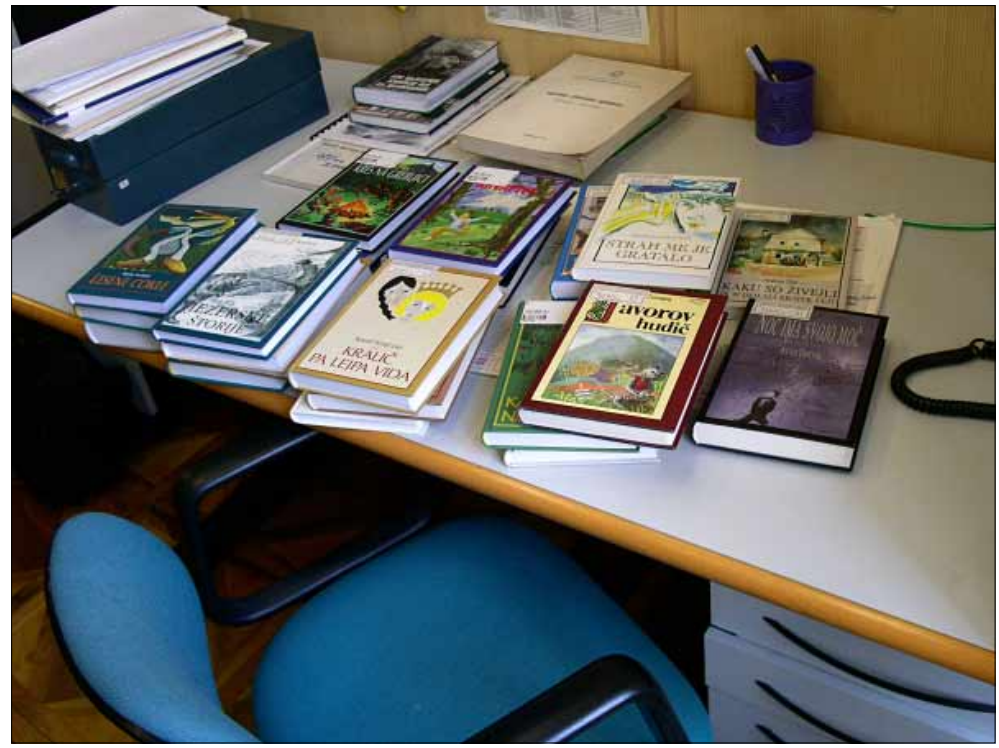

Photo 2. Publications on regional lore are attractively designed. Photo by Andres Kuperjanov 2004 
In 2003 the collection Düša na bicikli. Folklorne pripovedi iz Brkinov, doline Reke in okolice 'Soul on a Bicycle. Folklore of People Living in the Brkin Mountains and the Valley of Reke', consisting of more than 450 tales and compiled by Nada Kershevan and Marija Krebelj, was published. The anthology was illustrated by a local amateur artist. Next to traditional lore the collection includes historical narratives and oral history, stories about unusual events, festivities and healing. In a sense the selection reflects the ethnic and religious minorities of the area: the Orthodox Uskoks and the German-speaking Ko'evars. A preface provides an overview of regional history, the characteristic features of culture and language, typical sources of livelihood and festivities. The latest book reveals how much of what is Slovenian has been covered in the publications. More recent publications also have a $\mathrm{CD}$ with recordings of authentic dialectal texts attached, enabling to get a better idea of the dialectal varieties and oral lore. The project has so far been financed by the Slovenian Ministry of Education.

Od setve do žetve 'From Sowing to Harvest' is a concordance and interpretation of biblical motifs in the poetic folklore of Slovenia. This beautifully illustrated publication discusses the reflections of Old and New Testament legends, prayers and beliefs in folklore. The book is also illustrated with coloured reproductions of fragments of frescos and altarpieces, the earliest dating back to the $13^{\text {th }}$ century.

The interdisciplinary periphery is represented by a selection of poems of Slovenian soldiers who served in the German army during the WWII, complete with comments, biographical information and historical overview. Young men who were scattered all over Europe have written poems in their letters to homeland, or in their diaries. The topics include nostalgia for beloved people, home and homeland, including poetic images of the visited towns, among these also images of Tallinn. In the course of compiling these books and several others, she had established collegial contacts with representatives of corresponding societies and professions, and promoters of regional activities. A folklorist's activities are rarely limited to examining manuscripts in office silence, and are connected to people, groups and movements. 
Teoretični oris slovenstvene folklore 'Theoretical Features of Slovenian Literary Folklore' published in 2001, deals, according to its author, with the social objection to manifestations of authentic folklore and attempts to assess the field of study objectively. In this work the general idealising and commercialised folkloristic attitude is juxtaposed to authentic folklore, which is particularly evident in the often negative view expressed by articles in the Slovenian press. The over 400 pages long monograph attempts to comprise virtually all the main issues in folklore studies, and presents comparative analysis of the corresponding theories in the works of American, Scandinavian, German, Russian and Slovenian scholars. The author also systematises and categorises folkloristic terminology, observes the relationships of folklore with various neighbouring disciplines like linguistics and especially studies of dialectal varieties, literary theory; special attention is paid on the difference of folklore from trivia literature. Stanonnik treats folklore as a branch of literature. The book observes the spread of the term folklore in Slovenia, synonymic terms and their fields of meaning, also their systematisation. The terms are presented together with historical etymology, and the sc. standardised variants, a distinction is made between subordinate terms. Antonymy and analogy with literary theory have attracted wide attention. Central terminology of the $20^{\text {th }}$ century, like syncretism, theatrical elements, context, fieldwork, life stages of folklore, as well as issues of preservation and editing are presented in a categorised way and with explanatory comments. Towards the end of the monograph, Marija Stanonnik introduces seven paradoxes concerning literary folklore. The last of them states that popular prose is more personal than popular poetry, whereas in fiction poetry is far more personal. The book with an extensive summary in English is a useful material for anyone who is concerned with general theoretical issues. It is also a publication which, among other things, provides an intriguing comparison of issues discussed in American and Russian folklore studies and which indicates that the searches that occurred simultaneously on different continents had different approaches.

Marija Stanonnik is also the editor of the Slovenian folklore journal Slovenstvena folkloristika (financed by the Slovenian Congress). The journal in A4 format includes short articles intended for a wider public, providing information, overviews and sections like From Our Archives, Student Pages, Interview. 
The folklore series mentioned above are not the only ones that the folklorists and ethnologists of the Institute of Ethnology are associated with. A completely different kind of series is the hardcover anthology Slovensko propovedi. Zbirka Zakladnica slovenskih propovedi 'Slovenian Lore. Selections from Slovenian folklore', targeted to children and illustrated by professional artists. The volumes of this series are commented books with glossaries and short, 3-4 pages long prefaces. Anthologies of Slovenian lore mostly include archaic folk narratives which have disappeared from active usage. A fine example here is perhaps Visoko $v$ gorah, globoko $v$ voda 'High in the Mountains, Deep under Water' by Roberto Dapit and Monika Kropej, which mediates ogre lore, as most picturesque relief forms of Slovenia are believed to be done by ogres or have emerged as a result of their actions.

Zmago Shmitek's Odkod je ta naš svet? 'Where Has Our World Come From?', includes creation stories and origin myths, Sledovi potujočih duš 'Traces of Restless Souls', contains ghost lore and Monika Kropej's V somraku kraljestva palčkov in škratov 'In the Kingdom of Elves and Gnomes', includes stories about supernatural creatures.

Does one popular series of publication have advantages over another? Definitely, as one may provide modern people an opportunity to read the stories they still remember, the stories that tell of people and events that they know about, in print. It is a proof-collection which indicates the stability and abandonment of folkloric phenomena, enabling to understand the mechanisms of creation of new stories. This also enables to use dialectal variety, as the material is limited to a specific area. Another series conveys the best example of thematically systematised narratives and introduces the reader old and abandoned mythological motifs. Both approaches definitely have their audience, and we hope that the authors will carry on this valuable work.

In the Estonian tradition the golden age of folktale publications was the end of the $19^{\text {th }}$ and the beginning of the $20^{\text {th }}$ century, when literary men and writers, folklorists of different style and level of accomplishment, like Matthias Johann Eisen, compiled anthologies and thematic popular books. During the following half a century, various academic anthologies and selections were published. In the 
last quarter of the $20^{\text {th }}$ century, folk tale publication became the concern of authors and local enthusiasts, who anticipated the demand for mythological material and oral narrative history, publishing legends and folk tales, often retelling and editing these. A clearly evident discourse in the Estonian tradition is that of creating modern mythology, artificial legends and fairy tales. Reader's interest in such books has been active and keen, be the works authored by Edgar Valter, Eno Raud, Henno Käo or other famous Estonian writers and artists. Folklorists, in their turn, have contributed to satisfying the regional interests of local readers by publishing archival records. 